DOI: https://doi.org/10.32839/2304-5809/2021-8-96-8

удК 2(091)

Якуніна K.I.

Національний університет «Острозька академія»

\title{
ЗМІСТ І ФУНКЦІЯ РЕЛІГІЙНОГО МИСТЕЦТВА
}

\begin{abstract}
Анотація. У статті пропонуєьтся аналіз змісту на функціонального навантаження поняття «Релігійне мистецтво». Становлячи окремий вид мистецтва, релігійне мистецтво характеризуеться строгою канонічністю та обмеженістю, що не лише звужуе сферу діяльності автора, а й стає найвищим показником його вмінь та навичок. Мистецтвознавці й історики відзначають: в історії культури не існувало всеохоплюючого стилю в мистецтві, що виникло поза релігією. Питання релігійного мистецтва науковці найчастіше пов'язують із проблемами впливу канонів та догм на фрормування образів і сюжетів у творчості художників, письменників, архітекторів; або творчого підходу до розуміння того чи іншого явища релігії, що використовуеться при богослужінні, проповідях та ін. За таких умов багатоманітність та неузгодженність підходів у дослідженні релігійного мистецтвайого ж і актуалізує.
\end{abstract}

Ключові слова: релігійне мистецтво, творчість, релігія, сакральне, релігійний сюжет, канон.

Yakunina Kateryna

National University of Ostroh Academy

\section{CONTENTS AND FUNCTION OF RELIGIOUS ART}

Summary. In the article analysis of maintenance on functional loading of concept the religious art. Making the separate type of art, a religious art is characterized by strict canonical and narrow-mindedness, which not only narrows the sphere of activity of author but also becomes the greatest index of his abilities and skills. Religion and art is the spiritual phenomena in which emotional perception of objects plays a leading role. However much its depth, foreshortening and, finally, colouring, depend on the psychical settings of man, exactly they create an antithesis in perception of work of сакрального art. Excellent results of perception of works of painting of religious maintenance are in believers and infidel. For a believing man on the first plan there is an artistic not value, but religious maintenance of sacrum work. As a result of it an art, intertwined in the system of religious cult, purchased a double function: it becomes the mean of excitation and strengthening of religious senses, but simultaneously does not lose the aesthetically beautiful orientation. Representing eldritch, it does not stop to express earthly senses and aspirations of people, creates earthly perceptible offenses which are got from surrounding reality. A religious art is strictly canonical. However, during historical development of canon originality of his existence and functioning to a great extent was determined by the system of arts, which was formed in that or other world religion. Art critics and historians mark: in history of culture there was not all-embracing style in an art which arose up out of religion. The question of religious art research workers more frequent all bind to the problems of influence of canons and dogmas on forming of appearances and subjects in creation of artists, writers, architects; or creative going near understanding of the that or other phenomenon of religion which is used for divine service, sermons but other. Tracing the semantic filling of this phenomenon, him axiology and gnosiological essence, it is possible to come to the new conclusions.

Keywords: a religious art, creation, religion, sacrum, religious subject, canon.

Постановка проблеми. Особа е буттям, що живе на два способи буття в світі "sacrum i profanum" - світський і святий. Це два виміри екзистенції, два способи буття-в-світі е своерідними категоріями, вписаними в структуру особи, з допомогою яких вона пізнае світ. Суб'єктивне переживання е об'єктивним оскільки вказуе на дійсну структуру світу, виповненого sacrum. Не лише особа, але й увесь світ е скерований на sacrum. У релігійному баченні зв'язок 3 Богом становить конституційне значення для особи. Навіть арелігійна людина, що живе в сучасному десакралізованному світі, залишаеться всередині релігійною незалежно від ступеня усвідомлення собі самій цього факту. Більше того, конфлікт сучасного світу з релігіею та явище секуляризації вразили також й естетичну сферу і призвели до виникнення такого явища культури як мистецтво задля мистецтва. Саме тому, питання змісту та функції релігійного мистецтва набуває нової актуальності.

Аналіз останніх досліджень та публікацій. Питання релігійного мистецтва науковці найчастіше пов'язують із проблемами впливу канонів та догм на формування образів і сюжетів у творчості художників, письменників, архітекторів; або творчого підходу до розуміння того чи іншого явища релігії, що використовуеться при богослужінні, проповідях та ін. Проте, простеживши змістове наповнення цього явища, його аксіологічну та гносеологічну сутність, можна дійти нових висновків. Для досягнення ціеї мети використанні роботи В. Бодак, П. Герчанівської, Л. Рачеєвої, І. Федь та ін.

Ціль статті - аналіз змісту та функціонального навантаження релігійного мистецтва.

Виклад основного матеріалу. У сучасному світі, коли людство перебуває у стані екологічної, духовної, моральної кризи, коли життя людей втрачае сакральний зміст, і світ стае все більш механістичним, особливу увагу викликае такий феномен культури, як релігійне мистецтво. $\mathrm{У}$ широкому значенні слова релігійне мистецтво охоплюе всі художні твори, що характеризуються релігійною спрямованістю, релігійним сюжетом і апелюють до естетичного сприйняття релігійно оріентованої аудиторії, і в той же час націлені на їі розширення. У більш вузькому значенні 
термін “релігійне мистецтво” охоплюе всі ті естетико-художні фоеномени, що складають елементи релігійного культу і призначені для його обслуговування [10, с. 256]. Як ніякий інший вид культури, релігійне мистецтво, маючи культове призначення, служить віруючим зримою демонстрацією буття Бога, впливаючи одночасно на розум і на почуття людини. Релігійне мистецтво виникло разом із уявленнями людини про світ. Існуючі уявлення в культурно-релігійному середовищі дають фрорму бажанню людського духу висловитися. Це культурологічна, культурозберігаюча функція релігійного мистецтва. Суть релігійного мистецтва в тому, що, маючи змістовну частину, визначений сюжет і призначення, воно впливає на емоції, почуття і свідомість людини. Впливу тільки на розум було б недостатньо, а вплив тільки на почуття ні до чого не веде, адже розум визначає мету, смисл і зміст i, у кінцевому рахунку, саме він дає згоду на віру, на ту чи іншу картину світу, підтримуючи й підсилюючи їі. Як зазначає львівський фрілософр С. Черепанова, всі види мистецтва, які супроводжують релігійний культ, у сукупності виводять людину в інший стан сприйняття реальності: "Духовна музика, меси, реквіеми, що звучали під зводами храмів, створювали атмосфреру ірреальності” [1, с. 113].

Релігійне мистецтво - це спілкування людини з Богом як для художника, який його творить, так і для віруючого, який його сприймає. Релігійна тема, форма найбільшою мірою відповідала внутрішньому змісту душі як художника, так i оточуючих його людей. Сьогодні, коли проголошена свобода совісті, коли світ пройшов через "мракобісся" науки, люди, тим не менше, продовжують створювати світські твори мистецтва з релігійним сюжетом, а також будують нові храми, відновлюють зруйновані. Свангельські і інші релігійні сюжети служили і служать основою образів християнського релігійного мистецтва. Разом iз загальнолюдськими нормами ці сюжети закріпили такі сторони буття, як обмеженість, нерівномірність, суперечність діяльності людини. Образотворче мистецтво спеціалізувалося на художньому втіленні численних релігійних символів, складних геометричних орнаментів, а також орнаментів, побудованих на поєднаннях листя, квітів, плодів і т.п. У нерелігійному мистецтві зустрічаеться безліч прикладів подібного естетичного осмислення дійсності, але на відміну від релігійного, воно не орієнтується на вимоги культу і не прикладає до проблем людського буття критерії, освячені авторитетом трансцендентного початку. Релігійне ж мистецтво оцінюе прояви людської активності по їх відношенню до цього початку. Релігія, з одного боку, має в своєму розпорядженні систему ідей, образів і дій, що здатні стимулювати психологічний “простір" особи, де припинено бездушшя і безсердечності, можливі вища справедливість, доброта і милосердя. 3 іншого боку, вона забезпечуе і комфортне відношення до світу (як до творіння Бога) [6, с. 57].

Якщо говорити про релігійне й світське мистецтво, то в його основі, в першому випадку, лежить прагнення до вічного, до реалізації духовних цілей, очищення, катарсису, гармонії. У другому до матеріального і минущого. Зв'язок між ними чуттево-емоційна складова психічної структури людини. Але важливим для сакрального мистецтва є також не тільки його зміст, не тільки його функції, а його форма, стиль, що жорстко обмежують прийнятні тут способи вираження. Десакралізація та профанація релігійного мистецтва, на думку деяких авторів, відбувається не стільки через вибір тем чи сюжетів, скільки через вибір стилю й порушення канону. Так, Т. Буркхардт виключає із сакрального поля релігійне мистецтво Ренесансу й Бароко на тій підставі, що за стилем воно не відрізняється від світського [2].

Цей же автор упевнений, що світське мистецтво на релігійну тематику можливе, що світські форми в релігійному мистецтві допускаються, але сакральне мистецтво, світське за формою, неможливе. "Месію" Генделя можна вважати твором релігійного мистецтва, але сам жанр ораторії виводить іï за межі сакрального мистецтва. Тим більше не буде сакральною, незважаючи на сюжет, опера "Мойсей і Арон" чи відома рок-опера "Ісус Христос - суперзірка". Сакральні форми строго канонічні, і саме це захищає сакральне мистецтво від елемента особистісного, від присутності в ньому художника 3 його суто людським сприйняттям і емоціями [9].

Релігійне мистецтво прилучає людину до вічного, уможливлюе переживання причетності до Абсолюту й цим звільняе її від зовнішньої обумовленості власного існування, від неминучої тимчасовості перебування на Землі, кінцевості. Художник, транслюючи через свої твори власний внутрішній стан, дає іншим пережити те, чого, можливо, не було в їньому власному досвіді. Так через мистецтво надбання пошуку однієї душі стае загальнолюдським надбанням.

Разом 3 тим музеї, що зберігають витвори релігійного мистецтва, архітектурні ансамблі, що включають i будівлі культового призначення, концертні зали, де звучать твори, написані для церкви або на релігійні теми, дозволяють, особливо в зіставленні з мистецтвом, що прямо входить в систему культу, виявити таку сторону мистецтва, як поліфункціональнісь. Вона визначається перш за все відмінністю формальних і змістовних особливостей мистецтва [8, с. 26]. Якщо перші обумовлені сюжетом, символічною атрибутикою і зовнішніми особливостями образів художнього твору, то другі - специфрікою втілення ідейного задуму художника і фрункціональним призначенням твору. При цьому сам задум, його реалізація, так само як і суспільне місце (а значить, i сенс художнього рішення), залежать від соціально-історичного контексту епохи, коли воно створювалося. Відповідно, витвір релігійного мистецтва несе інформацію про ті суспільно-ідейні ситуації, до яких воно відноситься; утілюючи певний етично-естетичний, фрілософрський, політичний i релігійний зміст, воно викликає ідейні і емоційні асоціації як сучасників, так і представників подальших поколінь. У свою чергу, аудиторія, що сприймає твір, концентруе увагу на його формальних або змістовних сторонах. Так, “Трійця” А. Рубльова сприймалася сучасниками художника 3 погляду змісту як невід'ємна приналежність храму; нині відвідувачі Третьяковської галереї бачать в ній естетичний ідеал російського Середньовіччя на рубежі XIV-XV сторіч, що найглибше утілив в конкретноісторичній формі загальнолюдське прагнення до 
гармонії, миру і краси [4]. Подібний зсув акцентів можливий не тільки в діапазоні історичного часу, але і в межах сучасності. Різні люди можуть в один i той же час сприймати один і той же образ релігійного мистецтва в його переважно естетичному, етичному, фрілософрському, політичному, історичному, релігійному значеннях. Духовний розвиток особи, зміна їі інтересів і установок видозмінюють сприйняття художнього образу протягом індивідуального життя. У цьому психологічному середовищі кожного разу при сприйнятті витвору мистецтва здійснюеться "співтворчість": художній образ стає надбанням внутрішнього світу особи [5, с. 57]. Богословські уявлення про природу і призначення релігійного мистецтва спрямовують цей процес співтворчості переважно в русло створення, активізації і закріплення релігійних асоціацій і переживань. Проте процеси створення витворів релігійного мистецтва, передачі, розвитку і збагачення його традицій, освоєння їх вмісту в соціальній пам'яті так само як і індрормаційна, i емоційна взаємодія сучасників, більш ширші і багатопланові, чим релігійні інтерпретації цього мистецтва. Секуляризація послаблюе, як відомо, духовний і організаційний вплив церкви на мистецтво. Ряд його видів і жанрів розвивається відповідно до потреб світської культури (балет і комедія, симфонічні і концертні твори в музиці, цирк, кінематографріi). Менш визначеними стають церковні вимоги до релігійного змісту художніх творів. У протестантизмі вони зводяться, по суті, до захисту норм релігійної моральності художніми засобами i до затвердження мистецтвом божественної природи миру і людини. Католицизм після II Ватиканського собору здійснює програму освоєння церквою сучасного мистецтва за умови, якщо останне не відкидае ідей християнства, сприяє релігійним роздумам і переживанням. Суворіше, з канонічної точки зору, відбирає нові художні рішення православна церква; це стосуеться як будівництва нових храмів, так і їх оформлення. У музиці і поезії, пов'язаних з православною традицією, з'являються образи і сюжети, що відображають суперечності буття і свідомості людини нашого часу [4].

Мистецтво, будучи своєрідною моделлю творчого аспекту людської діяльності, орієнтує людину на творчу поведінку, стимулюе розвиток іï власних творчих здібностей. Релігійне (культове) мистецтво - ікони, церковні атрибути, храмова музика, живопис й архітектура - дає силу віруючому, ілюструє буття і велич Бога. Католицькі мистецтвознавці й теологи вважають, що художня творчість є способом виявлення божественної сутності в людині і в її справах. Якщо силою своєї волі Бог створюе людське, то живописець використовуе у своїй творчості створене для нього. Тому творче начало в людині сполучене із божественним. Отже, критерій істинності творів релігійного живопису полягає в інтенсивності творчого начала, де, продовжуючи себе в художнику, через творчість останнього Бог відкриваеться людям [9]. Воно наповнюе витвори, вкладеним авторами у твори, релігійним почуттям. Воно не залишає байдужим навіть атеїстів, які милуються досконалістю форм, мимоволі відчуваючи велич художника і ту емоційну вібрацію, що виходить від цих творів.
Суть релігійного мистецтва в тому, що, маючи змістовну частину, визначений сюжет і призначення, воно впливає на емоції, почуття і свідомість людини. Впливу тільки на розум було б недостатньо, а вплив тільки на почуття ні до чого не веде, адже розум визначає мету, смисл і зміст i, у кінцевому рахунку, саме він дає згоду на віру, на ту чи іншу картину світу, підтримуючи й підсилюючи їі. Безумовно, релігія використовує можливості психоемоційного впливу мистецтва на людину. Але коли говорять, що релігія не змогла б існувати без можливостей, наданих мистецтвом, то релігію неправомірно редукують до культово-ритуальних складових. Крім того, культ може бути дуже добре підтриманим і оформленим засобами мистецтва, але може значною мірою обходитися і без них. Так, творчість А. Рубльова здійснювалася у рамках християнсько-православних канонів, але разом з тим вона вийшла за його формальні межі й стала неповторним явищем релігійної культури. Ось чому, наприклад, його “Воскресіння Лазаря" “було, як каже мистецтвознавець В. Плугін, - суто індивідуальним фрілософрським роздумом, глибина й цілісність якого залишилися недоступними для його сучасників та послідовників" [1, с. 117]. Більше того, справжній художній канонічний твір, його настрій, найчастіше не можна передати за допомогою копії, хоча численні іконописні канонічні сюжети успішно репродукували.

Згідно 3 християнською релігійною традицією особлива роль відводиться субстанщіональним сакральним образам, які є джерелом і основою святості й мають власну долю (Ісус Христос, апостоли, святі). Нижче за ієрархією в релігійній культурі розташовані несубстаціональні образи, які лише проявляють буття священного, наприклад художні зображення сакрального.

Якщо образ - форма відображення дійсності в людській психіці, то знак є матеріальним об'єктом (артефрактом), що виступає в комутативному або трансляційному процесі аналогом іншого об'єкта (денотата), заміщує його. Інфрормація, яку надає знак про денотат (предмет, властивості, явища, поняття, дії та ін.), є значенням цього об'єкта, його змістом. У фрілософрї̈ мистецтва та релігії знак розглядається в контексті символічної діяльності людини. Знак стає символом тоді, коли його використання передбачає загальнозначущу реакцію не на сам денотат, а на його абстрактне значення (частіше цілий спектр значень), зв'язане з цим об'єктом.

На відміну від художнього образу символ не має безпосередньої схожості з об'ектом, він його визначає, але не відображає. У результаті цього мистецтво, вплітаючись у систему релігійного культу, набуло подвійної функції: воно стає засобом збудження і посилення релігійних почуттів, але одночасно не втрачає своєї естетичної спрямованості. Зображуючи надприродне, воно не перестає виражати земні почуття і прагнення людей, створює земні чуттеві образи, що отримані 3 навколишньої дійсності.

Релігійне мистецтво строго канонічне. В історичному плані канон - це стійка система, яка регулюе й організовує духовні структури суспільного життя взагалі і релігійного та художнього зокрема. Водночас канон був тим принципом, 
який визначав своєрідність побудови архітектурних релігійних споруд і організацію інших мистецтв навколо цього головного елемента релігійного культу $[11$, с. 300]. Проте, у ході історичного розвитку канону своєрідність його існування та фрункціонування значною мірою визначалася системою мистецтв, яка фрормувалася у тій чи іншій світовій релігії. Канон не міг абсолютно визначити своєрідність художнього мислення. Він лише у конкретних історичних проміжках, на думку Е. Яковлева, міг на певному змістовно-фрормальному рівні організувати сталість художньої цілісності [3, с. 234].

Треба тільки зауважити, що істотна відмінність між художнім і релігійним каноном полягає в тому, що, на думку О. Лосєва, “якщо художній канон - це кількісно структурна модель, то релігійний канон - це догмат, який пронизує не тільки кількісні рівні, а й змістовні, тобто якісні” [цит. за: 2]. Тому релігійний канон не допускає порушення не тільки побудови форми, а й змістовного начала. Так, канонізовані святі в християнстві мають абсолютно сталий набір якостей (а не тільки зовнішне вираження), які не можуть бути порушені або змінені.

Обмеження, що накладається встановленою універсальною знаковою системою, разом 3 тим захищає від іманентної однозначності, конкретизащії. Від неї також захищає символізм, котрим скрізь пронизане релігійне мистецтво. Гносеологічна природа символу робить його відповідним тим цілям, що ставить перед собою культове мистецтво - трансляція трансцендентного, очищення душі, наближення її до Бога. Символ не є зображенням трансцендентного (що в принципі неможливо, оскільки Бог є надформальною реальністю), а його “неподібною подобою".

Як і в будь-якому мистецтві, в релігійному мистецтві смисловим центром $є$ естетичний ідеал. На відміну від нерелігійного, він направлений до виявлення божественного початку, надихається релігійним сюжетом. Оскільки в традиційних релігіях його виявом є богослужіння, відповідність його вимогам і складає основу оцінок прекрасного 3 ортодоксально-релігійних позищій. Тип міфру зумовлюе естетичні оцінки в тій або іншій релігійній системі. Так, мистецтво, пов'язане з буддійським культом (наприклад, буддійські ікони або маски), оцінюеться християнином в руслі віровчення його власної релігії; правовірний мусульманин відкидає ренесансний живопис на релігійну тематику; для старообрядця православні ікони, написані в XVIII-XX ст., неприйнятні через їх невідповідність канонам староруського живопису, що склалися до середини XVII сторіччя [13, с. 256].

Символи відкривають вищі рівні реальності, не обмежуючи їх зміст мовними понятійними можливостями. Про значення символу в мистецтві говорять багато дослідників, у тому числі наша співвітчизниця С. Черепанова: "Символ належить до категорії doiлоcodpiï, науки, мистецтва, психології. У науці символ (математика, логіка) те ж саме, що знак. Символ у мистецтві - універсальна естетична категорія. Зміст символіки мистецтва відпові дає категоріями художнього образу, оскільки мистецтво піддається психологічній інтерпретації" [цит. за: 12].

3.Фрейд уперше провів аналогію між механізмом створення і сприйняття творів мистецтва та механізмом збудження франтазії. Він вважав, що спонукальним стимулом художньої творчості, як і франтазії, є незадоволені бажання [7, с. 7]. Саме вони лежать також у основі релігійних франтазій. Транспонуючи ідею Фрейда на сакральне мистецтво, доходимо висновку, що в духовному житті як художника, так і реципієнта воно надає можливість реалізувати ці бажання.

Перебіг франтастичних переживань, що виникають у художника і реципієнта, відбувається на емоційній основі. Емоції є безпосередньою чуттевою реакщією організму на зовнішній світ, знаходячи своє вирішення в образах франтазії. Власне, франтазії й емоції є не окремими процесами, а єдиним процесом i, за словами Л. Виготського, «ми вправі розглядати франтазію як центральне вираження емоційної реакції» [цит. за: 11, с. 40].

Висновки і пропозиції. I релігія, і мистецтво $€$ духовними феноменами, в яких емоційне сприйняття об’ектів відіграє провідну роль. Проте її глибина, ракурс i, нарешті, забарвлення залежать від психічних настанов людини, саме вони створюють антитезу у сприйнятті твору сакрального мистецтва. Відмінні результати сприйняття творів живопису релігійного змісту у віруючих та невіруючих. Для віруючої людини на першому плані $є$ не художність, а релігійний зміст сакрального твору. У результаті цього мистецтво, вплітаючись у систему релігійного культу, набуло подвійної фрункщії: воно стає засобом збудження і посилення релігійних почуттів, але одночасно не втрачає своєї естетичної спрямованості. Зображуючи надприродне, воно не перестає виражати земні почуття і прагнення людей, створюе земні чуттеві образи, що отримані з навколишньої дійсності.

\section{Список літератури:}

1. Бодак В. Релігія і культура: взаємовплив і взаємодія. Київ : Коло, 2005. 305 с.

2. Бодак В.А. Богословське осмислення проблеми релігії і культури: християнський контекст. Мультиверсул. Філософбський альланах. 2005. № 50. URL: www.filosof.com.ua

3. Введение в общее религиоведения : Учебник / Под ред. И. Яблокова. Москва : Книжный дом «Университет», 2001. 576 c.

4. Герчанівська П.Е. Художня та релігійна свідомість: спільне та особливе. Мультиверсул. Філософбський альланах. 2005. № 51. URL: www.filosof.com.ua

5. Киященко Н.И. Эстетическая деятельность в социологическом обществе. Москва : Исскуство, 1986. 208 с.

6. Поспелов Г.Н. Искусство и эстетика. Москва : Искусство, 1984. 325 с.

7. Предко О.І. Психологія релігії: формування та утвердження релігіезнавчої парадигми : автореферат дис. док. філос. наук. Київ, 2006. 57 с.

8. Разумцева Г. Моральні цінності українського народу та ритуальний закон церкви в поетичному фольклорі 19 ст. Українське релігієзнавство. 2000. № 14. С. 25-35.

9. Рачеєва Л.П. Релігійний живопис у системі позацековного мистецтва: культурно-історичний аспект. Мультиверсул. Філософбський альланах. 2006. № 54. URL: www.filosof.com.ua 
10. Релігіезнавчий словник / За ред. А. Колодного, Б. Ломовика. Київ : Четверта хвиля, 1996. 392 с.

11. Самохвалова В.И. Творчество и энергия самоутверждения. Вопросы ббилособбии. 2006. № 5. С. 34-47.

12. Федь I.А. Гуманістично-перетворювальна функція сакрального мистецтва. Мультиверсул. Філософбський альланах. 2004. № 44. URL: www.filosof.com.ua

13. Мазепа В.И., Азархин А.В., Михалев В.П. Художественная культура и эстетическое развитие личности. Киев : Научная мысль, 1989. 296 с.

\section{References:}

1. Bodak V. (2005) Religia i kultura: vzaiemovpliv i vzaiemodia [Religion and culture: co-operation]. Kyiv: Kolo, 305 p.

2. Bodak V.A. (2005) Bogoslovske osmislenia problemi religii i kulturi: hristiianskiy kontekst [Theological understanding of the problem of religion and culture: the Christian context]. Multiversum. Filosofskiy almanah, no. 50. Available at: www.filosof.com.ua

3. Vvedenie v obshchee religiovedenie [Introduction to general religious stadies] (2001) / Ed. I. Yablokov. Moscow: Knyzhnyi dom «Unyversytet», 576 p.

4. Gerchanivska P.Ye. (2005) Hudojnia ta religiyna svidomist: spilne ta osoblive [Artistic and religious consciousness: common and special]. Multiversum. Filosofskiy almanah, no. 51. Available at: www.filosof.com.ua

5. Kiyashchenko N.I. (1986) Esteticheskaia deiatelnost v sociologicheskom obshchestvie [Aesthetic activity is in sociological society]. Moscow: Isskustvo, $208 \mathrm{p}$.

6. Pospelov G.N. (1984) Iskustvo i estetika [Art and aesthetics]. Moscow: Isskustvo, 325 p.

7. Predko O.I. (2006) Psihologia religii: formuvania ta utverdgenia religiieznavchoi paradigmi [Psychology of religion: forming and claim of religious paradigm]. Kyiv, $57 \mathrm{p}$.

8. Razumceva G. (2000) Moralni cinnosti ukrainskogo narodu ta ritualniy zakon cerkvi v poetichnomu folklori 19 st. [Moral values of the Ukrainian people and the ritual law of the church in the poetic folklore of the 19th century]. Ukrainian religious studies, no. 14, pp. 25-35.

9. Racheieva L.P. (2006) Religiyniy zhivopis u sistemi pozacerkovnogo mistetctva: kulturno-istorichniy aspekt [Religious painting in the system of extracurricular art: cultural and historical aspect]. Multiversum. Filosofskiy almanah, no. 54. Available at: www.filosof.com.ua

10. Religiyeznavchiy slovnik [Dictionary of religious stadies] (1996) / Ed. A. Kolodniy, B. Lomovik. Kyiv, 392 p.

11. Samohvalova V.I. (2006) Tvorchestvo i energiya samoutverzhdenia [Creativity and the energy of self-affirmation]. Voprosi filosofii, no. 5, pp. 34-47.

12. Fed I.A. (2004) Gumanistichno-peretvoriuvalna funkcia sacralnogo mistetctva [The humanistic and transformative function of sacred art]. Multiversum. Filosofskiy almanah, no. 44. Available at: www.filosof.com.ua

13. Mazepa V.I., Azarhin A.V., Mihaliev V.P. (1989) Hudozhestviennaia kultura i tsteticheskoie razvitiye lichnosti [Artistic culture and aesthetic development of personality]. Kiev: Nauchnaya myisl, 296 p. 